\title{
Profil lesi stomatitis aftosa rekuren pada pasien di instalasi Ilmu Penyakit Mulut RSGM Unpad periode 2014-2015
}

\author{
Nurul Mukhliza Safely ${ }^{1}$, Nanan Nur'aeny ${ }^{1 *}$, Wahyu Hidayat ${ }^{1}$ \\ ${ }^{1}$ Departemen Ilmu Penyakit Mulut, Fakultas Kedokteran Gigi, Universitas Padjadaran, Bandung, \\ Indonesia
}

*Korespondensi: nanan.nuraeny@fkg.unpad.ac.id

\begin{abstract}
ABSTRAK
Pendahuluan: Stomatitis Aftosa Rekuren (SAR) merupakan penyakit mulut yang sangat sering terjadi pada masyarakat. SAR memiliki gambaran klinis berupa lesi ulserasi kecil berbentuk bulat atau oval dengan tepi kemerahan dan batas yang jelas serta dasar ulser berwarna putih atau kekuningan. Prevalensi SAR pada populasi dunia bervariasi antara 5\% sampai $66 \%$ dengan rata-rata $20 \%$. SAR diklasifikasikan dalam 3 tipe yaitu lesi minor, mayor, dan herpetiform; lesi sering ditemukan di mukosa labial, biasa diberikan terapi farmakologi berupa anti inflamasi topikal, serta membutuhkan masa penyembuhan 7-10 hari. Tujuan penelitian ini adalah mengetahui profil lesi SAR pada pasien di Instalasi Ilmu Penyakit Mulut Rumah Sakit Gigi dan Mulut Universitas Padjadjaran (RSGM Unpad) periode tahun 2014-2015. Metode: Jenis penelitian yang dilakukan bersifat deskriptif dari penelusuran data sekunder. Sampel penelitian yaitu rekam medis pasien dengan diagnosa SAR di RSGM Unpad periode 2014-2015. Hasil: Kasus SAR ditemukan sejumlah 47 kasus dari sejumlah 132 keseluruhan kasus penyakit mulut di instalasi penyakit mulut RSGM Unpad periode 2014-2015. SAR sebagian besar terjadi pada pasien dengan jenis kelamin perempuan daripada laki-laki, serta paling banyak ditemukan pada usia 20-29 tahun. Simpulan: Profil lesi SAR lebih banyak ditemukan tipe SAR minor, berlokasi di mukosa labial, dengan lama penyembuhan 7-14 hari dan penatalaksanaan farmakologi yang paling sering diberikan adalah topikal anti inflamasi kortikosteroid.
\end{abstract}

Kata Kunci : Profil lesi oral, stomatitis aftosa rekuren, ilmu penyakit mulut

\section{Profile of Aphthous Stomatitis lesions is repeated in patients in the installation of Oral Disease RSGM Unpad for the period 2014-2015}

\begin{abstract}
Introduction: Recurrent Aphthous Stomatitis (RAS) is a mouth disease that is very common in the community. RAS has a clinical feature of small round or oval ulceration with halo erythema, clear borders and white or yellowish ulcer bases. The prevalence of SAR in the world population varies between $5 \%$ to $66 \%$ with an average of $20 \%$. RAS is classified into 3 types, namely minor, major, and herpetiform lesions; lesions are often found in the labial mucosa, usually given pharmacological therapy in the form of topical anti-inflammation, and require a healing period of 7-10 days. The purpose of this study was to determine the profile of RAS lesions in patients in the Oral Disease Installation of Padjadjaran University Dental Hospital (RSGM Unpad) for the period of 2014-2015. Method: The type of research conducted is descriptive from secondary data tracking. The research samples were medical records of patients with SAR diagnoses at RSGM Unpad for the period 2014-2015. Results: The RAS cases were found in 47 cases from 132 cases of oral disease in the oral disease installation of RSGM Unpad for the 2014-2015 period. RAS mostly occurs in female patients than men, and most are at the age of 20-29 years. Conclusion: The profile of RAS lesions is more commonly found in the minor type, located in the labial mucosa, with a healing time of 7-14 days and also the most commonly prescribed drugs is topical anti-inflammatory corticosteroids.
\end{abstract}

Keywords: The profile of oral lesion, recurrent aphthous stomatitis, oral disease. 


\section{PENDAhUluan}

Stomatitis Aftosa Rekuren (SAR) adalah lesi ulserasi berulang yang hanya terbatas pada rongga mulut. Ulser merupakan suatu kondisi hilangnya permukaan epitel dan lapisan yang lebih dalam (hilangnya epitel yang meluas ke bawah lapisan sel basal), terasa sakit jika ditekan dan dapat menimbulkan pendarahan karena kerusakan sampai ke lamina propia. SAR merupakan penyakit mulut yang sangat sering terjadi pada masyarakat, bukan merupakan penyakit berbahaya yang mengancam jiwa, tetapi rasa sakit yang disebabkan oleh SAR dapat mengurangi kualitas kehidupan karena dapat mengganggu aktivitas sehari-hari seperti makan, menelan, ataupun berbicara. ${ }^{1}$

Prevalensi SAR pada populasi dunia bervariasi antara $5 \%$ sampai $66 \%$ dengan rata-rata $20 \%{ }^{1}$ Di Indonesia, data epidemiologi mengenai kasus SAR diantaranya memperlihatkan prevalensi SAR pada mahasiswa program studi Kedokteran Gigi Fakultas Kedokteran Gigi Universitas Sam Ratulangi sebesar $68,2 \%,{ }^{2}$ sedangkan di Klinik Ilmu Penyakit Mulut, Rumah Sakit Gigi dan Mulut (RSGM) Universitas Jember sepanjang tahun 2014 sebesar 14\%. ${ }^{3}$ Hasil penelitian sebelumnya menunjukkan data prevalensi SAR di Rumah Sakit Gigi dan Mulut Universitas Padjadjaran (RSGM Unpad) periode 2010 hingga 2012 mengalami peningkatan dari tahun ke tahun. ${ }^{4}$

SAR diklasifikasikan dalam 3 tipe berdasarkan berbagai penelitian mengenai ukuran lesi yang sebelumnya dilakukan oleh para ahli, yaitu lesi minor, mayor, dan herpetiform. SAR minor adalah tipe yang paling umum terjadi sekitar $80 \%$ pada penderita SAR, sedangkan SAR mayor $10-15 \%$ dan lesi herpetiform jarang terjadi. Hasil penelitian lain di Inggris pada 209 pasien penyakit mulut yang telah didiagnosa SAR, menunjukkan bahwa berdasarkan lokasi ditemukannya lesi biasanya terdapat pada mukosa labial (39\%), mukosa bukal (30\%), dan pada vestibulum $(29 \%)^{5}$

Penelitian mengenai SAR yang sudah dilakukan di RSGM Unpad sebagian besar membahas mengenai insidensi dan prevalensi SAR, namun belum terdapat hasil penelitian mengenai profil lesi SAR yang meliputi tipe, lokasi, lama penyembuhan, progresifitas lesi dan penatalaksanaannya, sehingga penelitian ini ditujukan untuk mengetahui profil lesi SAR pada pasien di Intalasi Ilmu Penyakit Mulut (IPM) RSGM Unpad berdasarkan hal-hal tersebut.

\section{METODE}

Jenis penelitian yang dilakukan adalah penelitian deskriptif. Populasi penelitian adalah rekam medis seluruh pasien yang berkunjung di Instalasi Ilmu Penyakit Mulut RSGM Unpad, Bandung, Indonesia. Sampel adalah status pasien dengan diagnosa SAR periode 2014-2015. Data sekunder didapatkan dari rekam medis pasien yang berkunjung di intalasi ilmu penyakit mulut RSGM Unpad periode 20142015, meliputi data pasien yaitu: jenis kelamin, usia, tingkat pendidikan, dan pekerjaan. Data terkait lesi dengan diagnosis SAR meliputi: tipe lesi, lokasi lesi, jumlah lesi, durasi SAR, progresifitas SAR serta terapi farmakologi yang diberikan. Instrumen penelitian terdiri dari data rekam medis pasien, alat tulis, formulir data penelitian, serta alat dokumentasi (kamera).

Penelitian ini dilakukan dengan mencatat dan mengumpulkan data yang diperlukan dari rekam medis pasien dengan diagnose SAR yang berkunjung di Instalasi Ilmu Penyakit Mulut RSGM Unpad, Bandung periode 2014-2015. Analisis data dilakukan dengan menggunakan distribusi frekuensi relative dan dideskripsikan dalam tabel. Rekomendasi etik penelitian kesehatan didapat dari Komite Etik Penelitian Kesehatan (KEPK) Unpad dengan nomor rekomendasi: 3599/UN6.FI/LT/2017.

\section{HASIL}

Hasil penelitian menunjukkan bahwa jumlah kasus stomatitis aftosa rekuren (SAR) adalah $47(35,60 \%)$ kasus dari 132 kasus yang merupakan keseluruhan kasus penyakit mulut di Instalasi Ilmu Penyakit Mulut RSGM Unpad periode 2014-2015. Hasil penelitian mengenai profil pasien pada tabel 1 , berdasarkan jenis kelamin, menunjukkan gambaran pasien SAR lebih banyak terjadi pada perempuan yaitu dengan jumlah sebesar 28 orang $(59,57 \%)$ dan laki-laki berjumlah 19 orang $(40,42 \%)$. Selain itu tabel 1 juga menunjukkan bahwa pasien SAR berdasarkan usia sebagian besar terjadi pada rentang usia 20-29 tahun dengan jumlah 42 orang $(89,36 \%)$ dan paling sedikit terjadi pada usia 40-49 tahun dengan jumlah 1 orang $(2,12 \%)$.

Hasil penelitian berdasarkan tingkat pendidikan sebagian besar SAR terjadi pada pasien dengan tingkat pendidikan Universitas dengan jumlah 44 orang atau 93,61\%, sedangkan paling 
sedikit terjadi pada tingkat pendidikan SMP sebesar 1 orang atau 2,12\%. Berdasarkan pekerjaan sebagian besar terjadi pada mahasiswa dengan jumlah 35 orang atau $74,46 \%$, paling sediki pada IRT dengan jumlah 1 orang atau sebesar 2,12\%.

Hasil penelitian pada tabel 2 menunjukkan bahwa dari sejumlah kasus SAR yang terjadi di Instalasi Ilmu Penyakit Mulut RSGM Unpad sebanyak 47 kasus, sebagian besar merupakan SAR tipe minor dengan jumlah 43 orang $(91,48 \%)$ diikuti dengan SAR tipe mayor sejumlah 4 orang $(8,51 \%)$ dan SAR tipe herpetiform tidak ditemukan selama periode 2014-2015. Selain itu berdasarkan jumlah lesi sebagian besar ditemukan lesi tunggal sebanyak 33 orang $(70,21 \%)$, sedangkan lesi multipel sebanyak 14 orang atau $29,78 \%$. Tabel 3 menunjukkan bahwa SAR berdasarkan lokasi ditemukannya sebagian besar di mukosa labial pada sebanyak 35 orang atau $55,55 \%$, dan paling sedikit terjadi di frenulum pada 1 orang $(1,58 \%)$.

Tabel 4 menunjukkan bahwa durasi penyembuhan dimulai dari munculnya ulser sampai sembuh setelah pemberian penatalaksanaan pada pasien SAR, sebagian besar sembuh pada durasi 7-14 hari (42,55\%), sembuh dalam kurang dari 7 hari $34,04 \%$ serta yang sembuh $>14$ hari sejumlah $23,40 \%$.

Tabel 1. Distribusi pasien SAR berdasarkan jenis kelamin, usia, tingkat pendidikan dan pekerjaan

\begin{tabular}{|c|c|c|c|c|c|}
\hline \multicolumn{2}{|c|}{ Profil Pasien } & \multirow{2}{*}{$\begin{array}{c}2014 \\
11\end{array}$} & \multirow{2}{*}{$\frac{2015}{8}$} & \multirow{2}{*}{$\begin{array}{c}\text { Jumlah } \\
19\end{array}$} & \multirow{2}{*}{$\begin{array}{c}\text { Persentase } \\
40,42\end{array}$} \\
\hline Jenis Kelamin & Laki-Laki & & & & \\
\hline & Perempuan & 13 & 15 & 28 & 59,57 \\
\hline \multirow{4}{*}{ Usia } & 10-19thn & 1 & 1 & 2 & 4,25 \\
\hline & 20-29thn & 21 & 21 & 42 & 89,36 \\
\hline & 30-39thn & 1 & 1 & 2 & 4,25 \\
\hline & 40-49thn & 1 & 0 & 1 & 2,12 \\
\hline \multirow{5}{*}{ Tingkat Pendidikan } & SD & 1 & 0 & 1 & 2,12 \\
\hline & SMP & 1 & 1 & 2 & 4,25 \\
\hline & SMA & 18 & 17 & 35 & 74,46 \\
\hline & Universitas & 4 & 5 & 9 & 19,14 \\
\hline & Pasca Sarjana & 0 & 0 & 0 & 0,00 \\
\hline \multirow{5}{*}{ Pekerjaan } & Pelajar & 1 & 1 & 2 & 4,25 \\
\hline & Mahasiswa & 18 & 17 & 35 & 74,46 \\
\hline & Pegawai Negeri & 2 & 3 & 5 & 10,63 \\
\hline & Pegawai Swasta & 2 & 2 & 4 & 8,51 \\
\hline & IRT & 1 & 0 & 1 & 2,12 \\
\hline
\end{tabular}

Tabel 2. Distribusi lesi SAR berdasarkan tipe dan jumlah lesi

\begin{tabular}{cccccc}
\hline \multirow{2}{*}{ Tahun } & \multicolumn{3}{c}{ Tipe lesi SAR } & \multicolumn{2}{c}{ Jumlah Lesi SAR } \\
\cline { 2 - 6 } & Minor & Mayor & Herpetiform & Tunggal & Multiple \\
\hline 2014 & 22 & 2 & 0 & 14 & 10 \\
2015 & 21 & 2 & 0 & 19 & 4 \\
\hline Jumlah/Persentase & $\mathbf{4 3 / 9 1 , 4 8 \%}$ & $\mathbf{4 / 8 , 5 1 \%}$ & $\mathbf{0 / 0} \%$ & $\mathbf{3 3 / 7 0 , 2 1} \%$ & $\mathbf{1 4 / 2 9 , 7 8 \%}$
\end{tabular}

Tabel 3. Distribusi lesi SAR berdasarkan lokasi lesi

\begin{tabular}{ccccc}
\hline Lokasi SAR & $\mathbf{2 0 1 4}$ & $\mathbf{2 0 1 5}$ & Jumlah & Persentase \\
\hline Mukosa Labial & 20 & 15 & 35 & $\mathbf{5 5 , 5 5}$ \\
Mukosa Bukal & 6 & 5 & 11 & 17,46 \\
Lidah & 2 & 1 & 3 & 4,76 \\
Gingiva & 4 & 3 & 7 & 11,11 \\
Dasar Mulut & 3 & 3 & 6 & 9,52 \\
Frenulum & 1 & 0 & 1 & 0,00 \\
Palatum & 0 & 0 & 0 & $\mathbf{1 0 0}$ \\
\hline Total & $\mathbf{3 6}$ & $\mathbf{2 7}$ & $\mathbf{6 3}$ &
\end{tabular}


Tabel 4. Distribusi durasi penyembuhan lesi pada pasien SAR

\begin{tabular}{ccccc}
\hline Durasi & $\mathbf{2 0 1 4}$ & $\mathbf{2 0 1 5}$ & Jumlah & Persentase \\
\hline$<7$ hari & 11 & 5 & 12 & 34,04 \\
$7-14$ hari & 8 & 12 & 20 & 42,55 \\
$>14$ hari & 5 & 6 & 11 & 23,40 \\
\hline Total & $\mathbf{2 4}$ & $\mathbf{2 3}$ & $\mathbf{4 7}$ & $\mathbf{1 0 0}$ \\
\hline
\end{tabular}

Tabel 5. Distribusi progresifitas lesi pada pasien SAR

\begin{tabular}{ccccc}
\hline Progresifitas Lesi SAR & $\mathbf{2 0 1 4}$ & $\mathbf{2 0 1 5}$ & Jumlah & Persentase \\
\hline Ulser (3-5 hari) & 24 & 23 & 47 & 64,38 \\
Erosif (6-14 hari) & 5 & 5 & 10 & 13,69 \\
Makula (>14 hari & 11 & 5 & 16 & 21,91 \\
\hline Total & $\mathbf{4 0}$ & $\mathbf{3 3}$ & $\mathbf{7 3}$ & $\mathbf{1 0 0}$ \\
\hline
\end{tabular}

Tabel 6. Terapi yang dilakukan pada pasien SAR periode 2014-2015

\begin{tabular}{ccccc}
\hline Penatalaksanaan & $\mathbf{2 0 1 4}$ & $\mathbf{2 0 1 5}$ & Jumlah & Persentase \\
\hline Triamsinolon acetonide & 12 & 12 & 24 & 31,57 \\
Khlorheksidin & 9 & 13 & 22 & 28,94 \\
Vitamin B12 & 6 & 7 & 13 & 17,10 \\
Vitamin B kompleks & 1 & 5 & 6 & 7.89 \\
Aloclair & 2 & 2 & 4 & 5,26 \\
Betadine & 2 & 1 & 3 & 3,94 \\
Ultravita & 2 & 0 & 2 & 2,63 \\
Asam Folat & 2 & $\mathbf{4 0}$ & 2 & 2,63 \\
\hline Total & $\mathbf{3 6}$ & & $\mathbf{7 6}$ & $\mathbf{1 0 0}$ \\
\hline
\end{tabular}

Tabel 5 menunjukkan bahwa penyakit SAR berdasarkan progresifitas lesinya, sebagian besar berbentuk ulser sebanyak 47 orang $(64,38 \%)$ terjadi pada 3-5 hari sejak terjadinya SAR. Diikuti dengan lesi makula sebanyak 16 orang atau 21,91\%, yang biasanya terjadi atau ditemukan ketika memasuki fase penyembuhan, sedangkan lesi erosive ditemukan pada 10 orang atau 13,69\%.

Tabel 6 menunjukan penatalaksanaan farmakologi yang banyak diberikan pada pasien SAR, yaitu pemberian Triamsinolon acetonide sebagai anti inflamasi steroid yang diberikan secara topikal, dengan jumlah 24 pemakaian atau 31,57\%. Pemberian khlorheksidin sebagai antiseptik juga ditemukan dengan jumlah 22 (28,94\%) dari 76 pemberian. Ultravita sebagi multivitamin dan asam folat sebagai vitamin, berdasarkan penelitian ini sangat jarang diberikan.

\section{PEMBAHASAN}

Hasil penelitian menunjukkan pada tahun 2014 jumlah kasus SAR yang terjadi yaitu 24 kasus dari 71 kasus penyakit mulut, sedangkan di tahun 2015 kasus SAR yang terjadi yaitu 23 kasus dari 61 kasus penyakit mulut yang ditemukan di Instalasi Penyakit Mulut RSGM Unpad. Prevalensi SAR pada periode 2014-2015 sebanyak 35.6\% kasus, hal ini sejalan dengan literatur yang mengatakan bahwa prevalensi SAR pada populasi dunia bervariasi antara 5\% sampai $66 \%$ dengan rata-rata $20 \%{ }^{2}$ Penelitian yang dilakukan di RSGM Unpad sebelumnya, periode 2009-2011 menunjukkan persentase terjadinya SAR sebesar 21,94\% atau sebanyak 163 kasus dari 743 kasus penyakit mulut, ${ }^{4}$ hal ini berarti prevalensi SAR meningkat seiring dengan berjalannya waktu.

Pasien SAR yang ditemukan sebagian besar terjadi pada pasien dengan jenis kelamin perempuan daripada laki-laki. Besarnya persentase SAR pada pasien dengan jenis kelamin perempuan karena perempuan memiliki faktor pemicu yang lebih banyak, seperti adanya fase menstruasi atau fase luteal dari siklus menstruasi, banyaknya pendarahan saat menstruasi, didukung asupan nutrisi yang tidak mencukupi kebutuhan regenerasi sel darah. Dua hari sebelum terjadinya menstruasi kadar progesteron dan estrogen akan turun secara mendadak karena tidak terjadinya pembuahan sehingga menyebabkan 
korpus luteum yang berfungsi untuk mensekresi progesteron tidak dapat bertahan. Penurunan estrogen mengakibatkan terjadinya penurunan aliran darah sehingga suplai darah utama ke perifer menurun, terjadi gangguan keseimbangan sel-sel termasuk rongga mulut, memperlambat proses keratinisasi sehingga menimbulkan reaksi yang berlebihan terhadap jaringan mulut dan rentan terhadap iritasi lokal dan memudahkan terjadi SAR. Penurunan kadar progesteron pada masa menstruasi mempunyai resiko lebih tinggi pada penderita SAR karena progesteron dianggap berperan dalam mengatur pergantian epitel mukosa mulut. ${ }^{6,7,8}$

Penelitian sebelumnya yang telah dilakukan di RSGM Unpad mengatakan bahwa dari 163 pasien SAR, 121 orang $(74,23 \%)$ diantaranya adalah pasien dengan jenis kelamin perempuan dan laki-laki berjumlah 42 orang atau $25,77 \%$. Hasil penelitian tersebut menunjukkan bahwa rasio terjadinya SAR pada pasien perempuan dibandingkan lakilaki memiliki perbandingan $3: 1,{ }^{4}$ sedangkan hasil penelitian ini menunjukkan rasio 3:2 (59.57: $40,42 \%$ ), hal ini berarti terjadi penurunan jumlah penderita perempuan dan peningkatan jumlah penderita laki-laki.

Hasil penelitian ini menunjukkan bahwa SAR sebagian besar terjadi pada rentang usia 20-29 tahun dan paling sedikit terjadi pada usia 40-49 tahun. Dalam penelitian sebelumnya di RSGM Unpad, juga ditemukan hal yang sama, SAR berdasarkan usia sebagian besar terjadi pada pasien dengan rentang usia 20 - 29 tahun, yaitu 84,66\%, dan jarang terjadi pada rentang usia $<10$ tahun dan pada kelompok usia 50-59 tahun dengan persentase yang sama 1,23\% ${ }^{4}$

Besarnya persentase penyakit SAR pada rentang usia 20-29 tahun karena usia tersebut merupakan usia produktif dengan beban pikiran yang semakin berat, sehingga dapat menimbulkan berbagai faktor pemicu, seperti kurangnya asupan nutrisi dan stress yang dapat menimbulkan SAR. Pada saat stress hormon glukokortikoid yang merupakan mediator utama respon terhadap stres menyebabkan peningkatan katabolisme protein sehingga menurunkan sintesis protein, yang mengakibatkan metabolisme sel terganggu sehingga rentan terhadap rangsangan atau mudah menyebabkan lesi. Berbeda pada pasien dengan rentang usia 4049 tahun, makin bertambahnya usia maka masa produktif dan hal-hal yang menjadi beban pikiran semakin dirasakan ringan, sehingga faktor pemicu SAR lebih sedikit. ${ }^{1,7}$ Tingkat pendidikan pasien sebagian besar adalah universitas/perguruan tinggi, dan berdasarkan pekerjaan sebagian besar adalah mahasiswa. Penelitian sebelumnya memperlihatkan SAR berdasarkan tingkat pendidikan juga paling banyak menyerang pasien dengan tingkat pendidikan universitas/perguruan tinggi yaitu sebanyak 10 orang $(41,67 \%)$ dan berdasarkan pekerjaan juga paling banyak menyerang mahasiswa yaitu sebanyak 14 orang $(58,3 \%)$. ${ }^{2,9}$ Tingkat pendidikan dan pekerjaan merupakan salah satu bagian dari status sosioekonomi yang lebih tinggi dan memiliki tingkat insidensi SAR yang tinggi juga. ${ }^{1,7}$ Mahasiswa yang bersekolah di perguruan tinggi memiliki tingkat stress yang tinggi dibandingkan dengan tingkat pendidikan lainnya. Dalam sebuah studi, SAR sering terjadi pada saat ujian dan saat-saat stress lain dalam masa perkuliahan. Faktor stress merupakan etiologi yang paling sering terjadi pada mahasiswa di jenjang perguruan tinggi. ${ }^{2,4,9}$

Berdasarkan tipe lesi, kasus SAR yang ditemukan sebagian besar merupakan SAR tipe minor, diikuti dengan tipe mayor dan tidak ditemukan SAR tipe herpetiform. Hal ini sejalan dengan penelitianpenelitian sebelumnya, SAR minor adalah tipe yang paling umum terjadi sekitar $80 \%$ pada penderita SAR, sedangkan SAR mayor 10-15\% dan SAR herpetiform jarang terjadi. ${ }^{1,5,7}$ Berdasarkan jumlah lesi sebagian besar ditemukan lesi tunggal, namun beberapa juga ditemukan lesi multipel. Lokasi lesi SAR sebagian besar terjadi pada mukosa labial, diikuti dengan mukosa bukal, dan paling sedikit terjadi di frenulum, serta tidak ditemukan pada palatum. Hal ini sejalan dengan hasil penelitian di Inggris yaitu pada 209 pasien penyakit mulut yang telah didiagnosa SAR, menunjukkan bahwa lesi biasanya muncul pada mukosa labial (39\%), mukosa bukal (30\%), atau vestibulum $(29 \%)^{5}$

Demikian juga hasil penelitian yang dilakukan tahun 2015 di RSGM PSPDG Universitas Sam Ratulangi menunjukkan hasil yang sejalan, bahwa distribusi lokasi terjadinya lesi SAR yaitu pada mukosa bibir/ labial (45,83\%), mukosa pipi (33,33\%), lidah $(12,50 \%)$, gingiva $(4,17 \%)$, dasar mulut $(4,17 \%)$ dan palatum $(0,00 \%) .{ }^{9}$ Hal ini karena mukosa labial, mukosa bukal, dasar mulut, ataupun ventral lidah memiliki struktur epitel non-keratin yang lapisan permukaannya tidak tahan terhadap abrasi dan tidak 
terikat kuat dengan lamina propia, sehingga mudah terbentuk ulser, serta karakteristik SAR lebih sering ditemukan pada mukosa non keratin dibandingkan dengan mukosa berkeratin seperti lidah, palatum durum dan attached gingiva. ${ }^{1,7}$

Durasi penyembuhan dari munculnya ulser sampai sembuh setelah pemberian penetalaksanaan farmakologi, pasien SAR sebagian besar sembuh pada durasi 7-14 hari, diikuti dengan $<7$ hari masa penyembuhan dan paling sedikit penyembuhan pada $>14$ hari. Hal ini berhubungan dengan tipe lesi SAR yang banyak ditemukan pada penelitian ini sebagian besar merupakan SAR tipe minor, dikatakan bahwa ulser minor membutuhkan durasi penyembuhan 7-14 hari, ulser mayor berdurasi lebih dari 2 minggu, serta ulser herpetiform berdurasi 7-14 hari. ${ }^{1,7}$

Berdasarkan progresifitas lesinya, sebagian besar lesi pada kunjungan pertama ditemukan berbentuk ulser atau pada 3-5 hari sejak terjadinya SAR, diikuti dengan lesi macula. Biasanya lesi makula terjadi ketika fase penyembuhan yaitu pada hari ke 15 atau lebih. Hal ini sesuai dengan literatur yang mengatakan bahwa SAR memiliki 3 tahapan perkembangan lesi yaitu tahap pra-ulserasi yang terjadi pada 18-72 jam pertama (1-3 hari), meliputi infiltrasi sel ke dalam inti vakuola epitelium. Tahap ini diikuti dengan degenerasi sel epitel suprabasal yang disertai oleh mononukleus, sebagian besar limfosit masuk ke dalam lamina propria. Tahap kedua yaitu tahap ulserasi, meliputi penambahan infiltrasi sel mononukleus pada jaringan. Tahap ini disertai edema lebih luas dan degenerasi dari epitelium, lalu berkembang menjadi lesi ulser sebenarnya dengan jaringan nekrotik dan membran fibrin yang menyelubungi lesi. Tahap ketiga yaitu tahap penyembuhan, meliputi regenerasi dari epitel, pada saat ini terjadi peningkatan jumlah sel yang tampak sebagai daerah kemerahan terlokalisir dan tidak menimbul. ${ }^{1,7}$

Ulser merupakan suatu kondisi hilangnya epidermis dan lapisan kulit yang lebih dalam (hilangnya epitel yang meluas di bawah lapisan sel basal), terasa sakit jika ditekan dan dapat kadang dapat menimbulkan perdarahan karena kerusakan sampai ke lamina propia. Erosi merupakan suatu kondisi hilangnya epitel di atas lapisan sel basal, dapat sembuh tanpa adanya jaringan parut. Kerusakan ulser dapat dibedakan dengan erosi karena kerusakan ulser lebih dalam dari erosi. Makula merupakan perubahan dalam warna kulit, bervariasi dalam ukuran dan bentuk, dan tampak sebagai pewarnaan pada kulit, dapat terbentuk dari dilatasi sementara dari pembuluh darah kapiler, sehingga tampak berwarna kemerahan atau eritema. ${ }^{1,7}$

Tatalaksana farmakologi yang banyak diberikan pada pasien SAR dalam penelitian ini, yaitu Triamsinolon acetonide sebagai anti inflamasi steroid dalam sediaan topikal. Pada saat SAR terjadi peradangan yang memerlukan anti inflamasi untuk menghindari kerusakan lebih lanjut. Steroid topikal merupakan obat efektif yang digunakan pada perawatan SAR. Bekerja sebagai antiinflamasi dan mengurangi rasa tidak nyaman. ${ }^{10}$ Pemberian klorheksidin juga merupakan pemberian yang umum diberikan, sebagai antiseptik yang diharapkan dapat menciptakan suasana rongga mulut yang mendukung ke arah percepatan perbaikan sel atau kesembuhan. Hal ini sejalan dengan penelitian terhadap mahasiswa di Jordania didapatkan pengobatan yang umum dipakai antara lain topikal analgesik/anestetik $21,7 \%$, obat kumur antiseptik $18,4 \%$, kortikosteroid topikal $17,2 \%$, antibiotik 3,0\%, analgesik $1,1 \%$, dan vitamin $0,7 \%{ }^{11}$ Berdasarkan hasil penelitian ini diharapkan dapat memberikan informasi ilmiah mengenai profil pasien dan lesi SAR yang sering ditemukan. Selanjutnya diperlukan kerjasama antara tenaga kesehatan dengan masyarakat untuk mensosialisasikan tentang SAR, upaya pencegahannya serta tatalaksana yang benar, sehingga individu penderita SAR dapat memperoleh kualitas hidup yang lebih baik.

\section{SIMPULAN}

Profil lesi stomatitis aftosa rekuren pada pasien di Instalasi Ilmu Penyakit Mulut Rumah Sakit Gigi dan Mulut Universitas Padjadjaran periode 2014-2015 lebih banyak ditemukan pada wanita, kelompok usia 20-29 tahun dengan tipe SAR minor, jumlah tunggal dan berlokasi di mukosa labial. Lama penyembuhan lesi SAR paling banyak antara 7-14 hari, sedangkan bentuk lesi yang paling sering ditemukan pada kunjungan pertama yaitu ulser yang pada kunjungan kedua/kontrol dapat berubah ke arah penyembuhan menjadi lesi erosi atau lesi macula. Penatalaksanaan farmakologi yang paling sering diberikan adalah Triamsinolon acetonide atau antiinflamasi kortikosteroid topikal. 


\section{DAFTAR PUSTAKA}

1. Greenberg MS, Glick M, Ship JA. Burket's oral medicine. $11^{\text {th }}$ ed. Hamilton Ontario: Bc Decker Inc. 2008. h. 396-8.

2. Suling PL, Tumewu E, Soewantoro JS, Darmanta AY. Angka kejadian lesi yang diduga sebagai stomatitis aftosa rekuren pada mahasiwa program studi kedokteran gigi fakultas kedokteran Universitas Sam Ratulangi. J E-Gi PAAI. 2013:1(2):106-13.

3. Sulistiani A, Hernawati S, Mashartini PA. Prevalensi dan distribusi penderita stomatitis aftosa rekuren (SAR) di Klinik Penyakit Mulut RSGM FKG Universitas Jember pada Tahun 2014. e-J Pust Kes 2018;4(3):595-602.

4. Ibrahim R. Gambaran stomatitis aftosa rekuren dalam hal profil pasien dan karakteristiknya. Bandung:Universitas Padjadjaran. 2012. h. 2-6.

5. Preeti L, Magesh KT, Rajkumar K, Karthik R. Recurrent aphthous stomatitis. J Oral Maxillofac Pathology 2011;15(3):252-7.

6. Farida S, Maria A, Utami S. Hubungan antara recurrent aphthae stomatitis dan kadar hormon reproduksi wanita. J Penelit Kes 2009;37(2):7986.

7. Scully C, Gorsky M, Lozada-Nur F. Diagnosis and management of recurrent aphthous stomatitis, a consensus approach. JADA 2013;134(2):200-7.

8. Balan U, Gonsalver N, Jose M, Girish KL. Symtomatic changes of oral mucosa during normal hormonal in healthy young menstruation woman. J Contemp Dent Pract 2012;13(2):178181.

9. Cindy CS, Pangemanan DHC, Christy M. Gambaran stomatitis aftosa rekuren di rumah sakit gigi dan mulut program studi pendidikan dokter gigi tahun 2015. J Ilm Farm UNSRAT. 2015;5.(2):2167.

10. Sawair FA. Recurrent aphthous stomatitis: Do we know what patients are using to treat the ulcers? J Alternat Complementary Med 2010;16(6):6515.

11. Safadi RA. Prevalence of recurrent aphthous ulceration in Jordanian dental patients. BMC Oral Health. 2009;9(31):1-5. 